Зубко А. Г., аспірантка

ДУ «Інститут економіки природокористування та сталого розвитку

Національної академії наук України» м. Киї, Україна

DOI: https://doi.org/10.30525/978-9934-26-068-1-25

\title{
ІНСТИТУЦІОНАЛЬНІ ЗМІНИ В УПРАВЛІННІ ЗРОШЕННЯМ ТА ДРЕНАЖЕМ ЯК ГОЛОВНИЙ ВАЖІЛЬ МОДЕРНІЗАЦЇ̈ ЗРОШУВАЛЬНОЇ СИСТЕМИ УКРАЇНИ
}

3 кожним роком глобальні кліматичні зміни все більше i більше впливають на сільське господарство України. Застарілість зрошувальної системи, яка була побудована ще в середині 70-х років минулого століття, разом 3 рекордною посухою, весняними морозами та буревіями зробили 2020-й рік одним із найскладніших для українських аграріїв. Всі ці негативні фактори підкреслили гостру необхідність комплексного реформування системи управління зрошенням та дренажем.

Питанням ефективного управління соціально-економічними відносинами в сфері зрошення та дренажу приділяють багато уваги у своїх працях вітчизняні та зарубіжні вчені, зокрема В.А. Сташук, В.С. Гоч, Л.Ф. Кожушко, А.В. Яцик, В.К. Хільчевський, І. М. Ромащенко, М.А. Хвесик, Л.В. Левковська, А.М. Сундук, В.А. Духовний.

Інституціональні зміни розглянемо як кількісні, якісні, а також сутнісні перетворення різних соціальних та економічних інститутів [5]. У контексті теми нашого дослідження звернемо увагу саме на сутнісні перетворення. Адже процес реформування системи управління зрошенням та дренажем передбачає в першу чергу перехід на ринкові відносини у сільському та водному господарстві.

Так, 1 липня 2021 року набуває чинності Закон України «Про внесення змін до деяких законодавчих актів України щодо 
умов обігу земель сільськогосподарського призначення», який відкриває ринок земельних ресурсів України [3]. Доцільність цього Закону продовжує викликати гострі суперечки та розбіжності. Проте з точки зору розвитку зрошення та дренажу, створення ринку землі має додатково стимулювати власників та орендаторів земельних ділянок сільськогосподарського призначення до залучення інвестицій та впровадження інновацій для ефективного зрошення.

Наступним кроком реформування управління зрошенням та дренажем стало затвердження у жовтні 2020 року Кабінетом Міністрів України плану заходів щодо впровадження Державної «Стратегії зрошення та дренажу до 2030 року». Для реалізації Стратегії зрошення та дренажу до 2030 року» мають бути виконані наступні завдання [4]:

1. Нарощення потенціалу зрошення та дренажу.

2. Модернізація міжгосподарських мереж.

3. Модернізація внутрішньо-господарських зрошувальних систем, яка передбачає модернізацію працюючих систем та відновлення працездатності пошкоджених систем, що не втратили свій ресурс.

4. Будівництво нових внутрішньо-господарських зрошувальних систем на міжгосподарських зрошувальних системах.

5. Відновлення дренажних систем у зоні осушення.

6. Модернізація працюючих дренажних систем.

7. Модернізація непрацюючих дренажних систем.

8. Відновлення дренажних систем у зоні зрошення.

9. Підвищення водозабезпечення для розвитку зрошення.

10. Наукове забезпечення реалізації Стратегії зрошення та дренажу в Україні на період до 2030 року.

Одним із очікуваних результатів у вищезгаданій Стратегії $є$ створення передумов для добровільного об'єднання водокористувачів в організації водокористувачів.

Для визначення правових, організаційних та економічних засад, умов створення та діяльності об'єднань водокористувачів, захисту їхніх прав та виконання обов'язків щодо спільного 
утримання, використання, експлуатації та технічного обслуговування об’єктів меліоративної інженерної інфраструктури у парламенті зареєстровано законопроект № 5202 «Про Організації водокористувачів (ОВК) та стимулювання гідротехнічної меліорації земель» [9].

На баланс організацій водокористувачів буде передано об'єкти меліоративної системи нижнього рівня, які перебувають у державній або комунальній власності чи $є$ безхазяйними. Обов’язок їх утримання та модернізації буде покладено на ОВК.

Таким чином, реформа в управлінні зрошенням та дренажем стимулюватиме залучення інвестицій для модернізації внутрішньогосподарських мереж, насосних станцій, використання сучасного енергоефективного обладнання, застосування новітньої дощувальної техніки та крапельного зрошення. Bce це в комплексі дозволить підвищити агроресурсний потенціал України та максимально можливо нівелювати вплив погодних умов на вирощування сільськогосподарських культур.

\section{Література:}

1. Витоптова В.А., Бондаренко Н.А. Еколого-економічні особливості крапельного зрошення. Наукові пращуі Кіровоградського нащіонального технічного університету. Економічні науки. 2010. Вип. 18(1). С. 214-219.

2. Державний комітет України по водному господарству Наказ №108 від 16.04.2008 № Про затвердження Інструкції з організації та здійсненні моніторингу зрошувальних та осушувальних земель». URL: https://zakon.rada.gov.ua/ laws/show/z0656-08.

3. Закон України «Про внесення змін до деяких законодавчих актів України щодо умов обігу земель сільськогосподарського призначення» від 31.03.2020 № 552-IX. URL: https://zakon.rada.gov.ua/laws/show/552-20\#Text.

4. Розпорядження Кабінету Міністрів України «Про схвалення стратегії зрошення та дренажу в Україні на період до 2030 року» від 14.08.2019 № 688-2019-p. URL: https://zakon.rada.gov.ua/laws/show/688-2019-\%D1\%80\#n10.

5. Катигробова О.В. Інституційні зміни як основа подолання суперечностей інноваційного розвитку. URL: http://www.investplan.com.ua/pdf/13_2013/9.pdf.

6. Левковська Л.В., Сундук А.М. Концептуальні засади економічної оцінки водних ресурсів у системі природного багатства України. URL: http://visen.knau.kharkov.ua/uploads/visn_econom/2014/7/7.pdf.

7. Матеріали сайту Biz.Ligazakon. URL: https://https://biz.ligazakon.net/ aktualno/8715_zemelna-reforma-shcho-zmnitsya-z-1-lipnya-2021-roku. 
8. Матеріали сайту Latifundist. URL: https://latifundist.com/infographics.

9. Проект Закону України «Про організації водокористувачів та стимулювання гідротехнічної меліорації земель» від 04.03.2021 №5202. URL: http://w1.c1.rada.gov.ua/pls/zweb2/webproc4_1?pf3511=71307.

10. Хвесик М.А., Левковська Л.В. Управління водними ресурсами: євроінтегративний вектор. URL: http://nbuv.gov.ua/UJRN/epod_2019_5_4. 